\title{
Changes in oxidative markers, endogenous antioxidants and activity of the enzyme acetylcholinesterase in farmers exposed to agricultural pesticides - a pilot study
}

\author{
Alterações em marcadores oxidativos, antioxidantes endógenos e na atividade da enzima \\ acetilcolinesterase em trabalhadores rurais expostos a pesticidas agrícolas - um estudo piloto
}

\author{
Camila Murussi ${ }^{\mathrm{I}}$ Roberta Cattaneo Horn $^{\mathrm{I}^{*}}$ Adriana Santi ${ }^{\mathrm{II}}$ Barbara Estevão Clasen ${ }^{\mathrm{II}}$ \\ Gabriel Reis ${ }^{\mathrm{I}}$ Daniela Souza $^{\mathrm{I}}$ Josiane Woutheres Bortolotto $^{\mathrm{I}}$ \\ Candida Elisa Manfio ${ }^{I}$ Vania Lucia Loro ${ }^{I I}$
}

\section{ABSTRACT}

Agricultural practices are directly related to the use of pesticides, which indiscriminately and without due care may contribute to the occurrence of numerous intoxications. Several studies have demonstrated the relationship of certain pesticides and the occurrence of oxidative stress and therefore, in recent years have developed methods of analysis of several biomarkers of cellular damage that can be measured and quantified. In this context, the objective of this study was to evaluate the possible changes in biochemical markers: glutamic aspartate aminotransferase (AST), alanine aminotransferase (ALT), creatinine, urea, total protein, and oxidative markers such as lipid peroxidation, damage to proteins and the activity of the enzymes acetylcholinesterase (AChE) and catalase (CAT) in farmers exposed to different pesticides for at least five years from Ibirubá - RS city. With the exception of AST and $A L T$, the results showed a significant difference between the mean total protein, urea and creatinine in the control group, showing that no changes in liver or kidney function of rural workers. In the oxidative parameters, there was a decrease in AChE activity and CAT in the control group; there were an increase in protein carbonyl and a decreased on TBARS compared to control group. Therefore, the results demonstrated a change in oxidative status of rural workers compared with the control group, mainly by possible inhibition of AChE activity and the occurrence of oxidative stress without showing changes in biochemical parameters.

Key words: rarmers, oxidative stress, TBARS, protein carbonyls.

\section{RESUMO}

As práticas agrícolas estão diretamente relacionadas com o uso de agrotóxico, que, de forma indiscriminada e sem o devido cuidado, podem contribuir para a ocorrência de inúmeras intoxicações. Diversos estudos demonstraram a relação de determinados pesticidas e a ocorrência do estresse oxidativo $e$, portanto, nos anos recentes, tem-se desenvolvido métodos de análise de diversos biomarcadores de dano celular, o qual pode ser medido e quantificado. Nesse contexto, o objetivo deste estudo foi avaliar as possíveis alterações nos marcadores bioquímicos: aspartato aminotransferase (AST), alanina aminotransferase (ALT), creatinina, ureia, proteína total, e marcadores oxidativos como: a peroxidação de lipídios, danos nas proteínas e a atividade das enzimas acetilcolinesterase (AChE) e catalase (CAT), em agricultores da cidade de Ibirubá, RS, expostos a diferentes agrotóxicos por pelo menos cinco anos. Com exceção da AST e da ALT, os resultados mostraram diferença significativa entre as médias das proteínas totais, ureia e creatinina, no grupo controle, mostrando que não houve alterações na função hepática ou renal dos trabalhadores rurais. Nos parâmetros oxidativos avaliados, houve uma diminuição da atividade da AChE e da CAT em relação ao grupo controle; um aumento das proteínas carboniladas e uma diminuição dos níveis de TBARS em relação ao grupo controle. Portanto, os resultados demonstram uma alteração oxidativa nos trabalhadores rurais, comparados com o grupo controle, principalmente pela possível inibição da AChE e ocorrência do estresse oxidativo, sem demonstrar mudança nos parâmetros bioquímicos analisados.

Palavras-chave: agricultores, estresse oxidativo, TBARS, proteínas carboniladas.

\section{INTRODUCTION}

Agricultural pesticides are among factors which contaminate the natural habitat. They have adverse effects on the environment when used against pests, undesirable herbs and agricultural diseases. Currently, pesticides pose a risk to humans especially those professionally involved in their production, the workers in agriculture and the general population which consumes contaminated food products (TROUDI et al., 2012).

'Laboratório de Bioquímica, Centro de Ciências da Saúde, Universidade de Cruz Alta (UNICRUZ), Campus Universitário Dr. Ulisses Guimarães, Rod. Municipal Jacob Della Méa, km 5.6, Parada Benito, 98020-290, Cruz Alta, RS, Brasil. E-mail: robertacattaneo82@gmail.com.*Autor para correspondência.

IILaboratório de Bioquímica Adaptativa, Departamento de Química, Universidade Federal de Santa Maria (UFSM), Santa Maria, RS, Brasil. Received 04.15.13 Approved 12.23.13 Returned by the author 05.27.14 
Thus, the widespread use of pesticides in agriculture results in continuous exposure of human populations and several studies have reported associations between the exposure to agricultural chemicals and health alterations. Low-level exposure to pesticides is known to produce a variety of biochemical changes such as target cell/receptor binding, protein and DNA adduct formation, as well as induction or inhibition of enzymes (LÓPEZ et al., 2007; SANTI et al., 2011). However, these investigations are often limited by self-reported exposures and little advance is obtained regarding the biological mechanisms linking exposure to pesticides and health outcome (MUNIZ et al., 2008).

A valuable indicator of the relationship between exposure to pesticides and health problem is the determination of cholinesterase. The inhibition of these enzymes by organophosphates and carbamates leads to the accumulation of acetylcholine and butyrylcholine thus the body starts to produce a series of undesirable events, such as and lower back pain, headache, among others (LINARES et al., 2005).

Oxidative stress is caused by excessive production of reactive oxygen species (ROS) and reactive nitrogen species (RNS), among other reactive species. Such substances are an integral part of human metabolism and are observed in various physiological conditions (VASCONCELOS et al., 2007). In the body, these reactive species are involved in energy production, in phagocytosis, in the regulation of cell growth and intracellular signaling as well as in the synthesis of important biological substances. On the other hand, these reactive species have some adverse effects such as peroxidation of membrane lipids and protein tissue carbonylation. These effects may lead to several pathologies such as arthritis, hemorrhagic shock, heart disease, cataracts, cognitive dysfunction, and cancer (BARREIROS \& DAVID, 2006).

The monitoring of the occurrence of oxidative stress is accomplished through oxidative and antioxidant markers. Oxidative markers are analyzed by quantifying thiobarbituric acid reactive substances (TBARS) and levels of protein carbonyls. Given that, lipid peroxidation (LPO), which is the major contributor to the loss of cell function, as well as DNA damage, enzyme inactivation, and hormone oxidation are indicators of oxidative cell damage (RUAS et al., 2008). LPO, in particular, has been suggested to be one of the mechanisms of pesticideinduced toxicity (MANSOUR \& MOSSA, 2009; SANTI et al., 2011). On the other hand, antioxidant markers are observed by analyzing the activity of enzymes such as catalase (CAT) that is ubiquitously present in a wide range of aerobic cell types and in red blood cells where it is found as a soluble protein that may protect against peroxidation of hemoglobin. Because of the important role of CAT in the scavenging process of $\mathrm{H}_{2} \mathrm{O}_{2}$, the investigation of possible changes in the activity of this enzyme under the influence of commonly used herbicides seems to be essential (DERESZ et al., 2007).

Biochemical changes are considered important biological indicators, being a sensitive response of the body to harmful exposures front health. These changes allow you to monitor the degree of exposure and prevent irreversible effects. Liver enzymes aspartate aminotransferase (AST), alanine aminotransferase (ALT), are used as biological markers of liver abnormalities (AMORIM, 2003). When there are problems with renal filtration, in most cases there is an increase in blood levels of creatinine and urea, together with a reduction in total protein concentration in the blood (LEITE et al., 2002; GAW et al., 2008). The levels of the AST enzyme increase in any form of acute arterial occlusion and in ischemia as well, in cirrhosis, biliary obstruction, infectious and toxic hepatitis (ELY et al., 2000). And, the ALT increase occurs exclusively in liver changes (GAW et al., 2008). Furthermore, the creatinine, the urea, the uric acid and the total protein are used as biomarkers of renal changes, assessing the ability of the kidneys to filter the plasma in the glomeruli by measuring the clearance of the same (GAW et al., 2008), therefore these markers can be used to verify if renal function is impaired by exposure to agricultural pesticides (OGA, 2003).

This work was part of a pilot study that aimed to evaluate biochemical markers such as AST, ALT, creatinine, urea, total protein, and oxidative markers such as lipid peroxidation, damage to proteins and the activity of the enzymes acetylcholinesterase (AChE) and catalase (CAT) in farmers, worked at Fazenda Itaíba in the district of Ibirubá, Rio Grande do Sul, Brazil, exposed to different pesticides for at least five years. The county has much of its population living in rural areas $(n=3968 ; 20.5 \%$ of total population) with agricultural production of soybeans, wheat and corn mostly, which leads to the use of a large amount of pesticides (IBGE, 2010).

\section{MATERIALS AND METHODS}

Samples

We selected 15 individuals who worked more than five years in direct contact with pesticides in Fazenda Itaíba (exposure group), which is situated 
in the municipality of Ibirubá RS-Brazil and 15 individuals who worked in offices and never had direct contact with pesticides (control group). In October, 2011, blood samples were collected from all individuals participating which were analyzed.

For the selection, volunteers answered an informational questionnaire which served for inclusion and exclusion of individuals in the study. The participants were descendents of Italians and Germans, male and had mean age $42 \pm 11$ years. Volunteers with acute, chronic diabetics, suffering from hypertension, hyperlipidemia, obesity with a Body Mass Index (BMI) $\geq 30 \mathrm{~kg} \mathrm{~m}^{-2}$, and/or smokers who drank more than 2 times a week were excluded from the selection.

All the participants expressed written consent through the Term of Consent that was provided. Thereafter, blood samples were taken from individuals in study participants by venipuncture after cleansing the site. We used syringes and tubes (without anticoagulant) for the collection and cotton for the local press to prevent bruising. Afterwards, samples were processed at the biochemistry laboratory at the (UNICRUZ) and the serum was separated, for subsequent biochemical determinations in the laboratory of biochemistry at the (UNICRUZ) and measurements the AChE activity and oxidative stress biomarkers, in the adaptive laboratory of biochemistry at the Federal University of Santa Maria (UFSM) in November, 2011.

Analytical collections

Biochemical measurements

The measurement of creatinine, total protein, urea, aspartate aminotransferase (AST), alanine aminotransferase (ALT) was performed in serum by using specific techniques of colorimetric and kinetic method as indicated by the manufacturer of the kits $\left(\right.$ Labtest $\left.^{\circledR}\right)$.

\section{Acetylcholinesterase (AChE)}

The AChE (EC 3.1.1.7) activity was measured in serum, using the method described by ELLMAN et al. (1961). Absorbance was measured by spectrophotometry at $412 \mathrm{~nm}$ during $2 \mathrm{~min}$. Enzyme activity was expressed as $\mu \mathrm{mol}$ of ASCh hydrolyzed/min/mg protein.

\section{Oxidative stress biomarkers}

Lipid peroxidation was estimated in serum by a TBARS assay, through a malondialdehyde (MDA) reaction with 2-thiobarbituric acid (TBA), which was optically measured. TBARS levels were expressed as nmol $\mathrm{MDA} / \mathrm{mg}$ protein according to BUEGE \& AUST (1978).
Protein carbonyl biomarkers

Protein carbonyl content was assayed in serum by the method described by YAN et al. (1995) with some modifications. Soluble protein $(1.0 \mathrm{~mL})$ was reacted with $10 \mathrm{mM}$ DNPH in $2 \mathrm{~N}$ hydrochloric acid. The total carbonylation was calculated using a molar extinction coefficient of $22.000 \mathrm{M} \mathrm{cm}^{-1}$.

\section{Catalase (CAT)}

Catalase (EC 1.11.1.6) activity was assayed in serum, by ultraviolet spectrophotometry (NELSON \& KIESOV, 1972). The change of $\mathrm{H}_{2} \mathrm{O}_{2}$ absorbance in 60 s was measured by spectrophotometry at $240 \mathrm{~nm}$. The catalase activity was calculated and expressed in

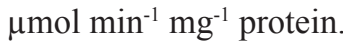

Total protein

Protein was determined Protein carbonyl content was assayed in serum, by the Comassie blue method using bovine serum albumin as standard. The absorbance of the samples was measured at $595 \mathrm{~nm}$ (BRADFORD et al., 1976).

\section{Statistical analysis}

Results were expressed as mean \pm standard error (SEM) and analyzed by Student's T-test, considering values significantly different at $\mathrm{P}<0.05$, using Graph Pad Prism 5 program.

\section{RESULTS AND DISCUSSION}

Besides serving for the exclusion and inclusion of participants in the study, the questionnaire showed some important data, such as, farmers had been exposed to pesticides for more than 20 years (same average service time in the agricultural area reported) and had been directly in contact with agricultural products within 15 days preceding the day of sample collection. In addition, rural workers responded about the pesticides used to control pests and diseases in crops and frequency of use in the field (Table 1). They were also questioned about using personal protective equipment (PPE, Table 2), showing that most of them wear gloves $(n=11 ; 73 \%)$, masks and overalls $(n=12 ; 80 \%)$, and boots $(n=13$; $86.7 \%$ ). Data showing a major exhibition of these farmers to agricultural pesticides, since according to VEIGA et al. (2007), PPE is used to ensure the protection against external chemical agents.

These markers of renal changes carried out in this study were not significantly altered in the group of farmers when compared to the control group (Table 3). From these data one can have an idea that the 
Table 1 - Pesticides used by farmers in Ibirubá, RS, Brazil (n=number of individuals who used the product).

\begin{tabular}{|c|c|c|c|}
\hline Active ingredients & Toxicological class* & № & $\%$ \\
\hline Glyphosate & IV & 15 & 100 \\
\hline Iprodione & IV & 3 & 20 \\
\hline Imidacloprid & IV & 3 & 20 \\
\hline Acephato & IV & 2 & 13.3 \\
\hline Atrazine + simazine & III & 9 & 60 \\
\hline Metsulfuron methyil & III & 9 & 60 \\
\hline Chlorimuron-Etyl & III & 4 & 26.7 \\
\hline Triazinas & III & 5 & 33.3 \\
\hline Azoxystrobin+Cyproconazole & III & 6 & 40 \\
\hline Fipronil & III & 3 & 20 \\
\hline Lambdacyhalothrin & III & 13 & 86.7 \\
\hline Thiodicarb & III & 4 & 26.7 \\
\hline Lambdacyhalothrin & III & 11 & 73.3 \\
\hline Permethrin & III & 5 & 33.3 \\
\hline Solvent Naphtha + Pyraclostobin & II & 11 & 73.3 \\
\hline Mancozeb & II & 2 & 13.3 \\
\hline Imidacloprid + thiodicarb & II & 7 & 46.7 \\
\hline Metalaxyl-M + Mancozeb & I & 3 & 20 \\
\hline Dichlorophenoxyacetic & I & 4 & 26.7 \\
\hline
\end{tabular}

Note: Data confirmed by the technical manager of the property.

Chemicals used in the period of maximum 30 days prior to the collection of blood from agricultural producers.

Toxicological class was according on ANVISA (2013).

renal function of farmers apparently was not changed, however more parameters activities kidney, such as renal clearance should be performed one confirmation these results. Furthermore, in this study, the levels of these enzymes AST and ALT were not significantly increased, but decreased, in agricultural workers, when compared with control (Table 3), showing that the exposure to agricultural pesticides have caused damage to liver tissue. Importantly, the decreases in the levels of AST and ALT are considered normal, according to GAW et al. (2008), since this indicates that there is no breakage of hepatic cells, and therefore these enzymes do not overflow into the blood.

The determination of AChE activity in blood is a great consideration in the diagnosis of poisonings caused by reversible and irreversible inhibitors of this enzyme including pesticides (SANTI et al., 2011). The present study reports a significant decreased AChE activity in the agricultural workers when compared to control subjects see in table 3 . $\mathrm{AChE}$ is an enzyme that catalyses the hydrolysis of acetylcholine (ACh) into choline and acetate in the synaptic cleft. When inhibition of AChE activity occurs, the neurotransmitter ACh is not hydrolyzed in the nerve synapses or neuromuscular junctions, causing an abnormal amount of ACh at these sites, which leads to an over-activation of brain and muscular tissue (ROEX et al., 2003; CATTANEO et al., 2011), which can headache, backache and muscle aches, as reported by farmers in this study and develop disease pathologies more serious longterm related to the SNC (OGA et al., 2003).

Furthermore, the decrease in AChE activity may be related to the neuroimmunoregulatory role of this enzyme. This decrease in this activity of AChE is in agreement with previous reported studies (LINARES et al., 2005; CATANO et al., 2008; JINTANA et al., 2008; SIMONIELLO et al., 2010; ASTIZ et al., 2011). And this result may be related to headaches and muscle that were reported by $60 \%$ of farmers, considering that for OGA (2003), these clinical manifestations may appear in most cases of pesticide poisoning type carbamates and organophosphates wherein the acetylcholinesterase shown to be inhibited. Moreover, according to this author, some organophosphate pesticides can lead to the development of a delayed neuropathy, making it

Table 2 - Personal protective equipment (PPE) used by farmers in Ibirubá $(\mathrm{n}=15)$.

\begin{tabular}{lll}
\hline PPE & № $^{\mathrm{o}}$ & $\%$ \\
\hline Boots & 13 & 86.7 \\
Cap & 3 & 20 \\
Gloves & 11 & 73 \\
Masks and overalls & 12 & 80 \\
\hline
\end{tabular}


Table 3 - Parameters assayed in plasma farmers. Expressed values are the mean \pm standard error (SEM); $n=15$

\begin{tabular}{|c|c|c|c|c|}
\hline Parameter & Reference & Control & Exposed & $\mathrm{P}$ \\
\hline Total protein $\left(\mathrm{mg} \mathrm{dL}^{-1}\right)$ & $6-8$ & $6 . .9 \pm 0.2$ & $6.5 \pm 0.1$ & 0.08 \\
\hline Creatinine $\left(\mathrm{mg} \mathrm{dL}^{1}\right)$ & $0.4-1.3$ & $1.5 \pm 0.1$ & $1.3 \pm 0.1$ & 0.25 \\
\hline Urea $\left(\mathrm{mg} \mathrm{dL}^{1}\right)$ & $5-39$ & $40.5 \pm 2.3$ & $40.6 \pm 1.9$ & 0.97 \\
\hline $\operatorname{ALT}\left(\mathrm{U} \mathrm{mL}^{1}\right)$ & $4-36$ & $13.6 \pm 1.7$ & $11.5 \pm 1.4^{*}$ & 0.025 \\
\hline $\operatorname{AST}\left(\mathrm{U} \mathrm{mL}^{1}\right)$ & $4-32$ & $39.9 \pm 3.3$ & $32.6 \pm 3.7 * *$ & 0.00 \\
\hline Catalase ( $\mathrm{Ug}^{1}$ protein $)$ & - & $140.38 \pm 4.6$ & $123.8 \pm 4.3 * *$ & $<0.00$ \\
\hline $\mathrm{AChE}\left(\mu \mathrm{mol} \mathrm{min} \mathrm{mg}^{-1} \mathrm{mg}^{-1}\right.$ protein $)$ & - & $0.03 \pm 0.00$ & $0.01 \pm 0.00^{* *}$ & 0.00 \\
\hline
\end{tabular}

*Significant differences in the exposed group compared to the control group $(\mathrm{P}<0.05)$.

important to follow these individuals who are exposed chronically to pesticides.

Malondialdehyde (MDA), a highly reactive bifunctional molecule, is an endproduct of membrane LPO. MDA has been shown to cross-link erythrocyte phospholipids and proteins. This process results in impairment of the membrane-related functions, leading ultimately to diminished survival (CIMEN, 2008). In this context, some authors demonstrated who increased levels of TBARS are proportional the chances of developing diseases, such as cardiovascular diseases, respiratory problems or cancer (ANDRADE Jr et al., 2005; BAGIS et al., 2005). However, in this study the TBARS decreased significantly in the group exposed to pesticides when compared to the control group (Figure 1). This result occurred, probably due to a marker TBARS be very unstable, and there may be in their levels in chronic exposure to toxic substances, as is the case in this study (DALLE DONNE et al., 2003).
The figure 2 shows the significative increased protein carbonyl levels on farmers with respect to individuals not exposed to pesticides. Thus, considering that the carbonylation protein is a marker commonly used for the assessment of oxidative damage, as the carbonylation is an irreversible modification of proteins, causing changes in structure, function and protein degradation (SLEDZINSKI et al., 2008). And that according DALLE DONNE et al. (2003), the usage of carbonylated proteins groups as biomarkers of oxidative stress has some advantages in comparison with the measurement of other oxidation products, such as TBARS, because of the relative early formation and the relative stability of carbonylated proteins, these results indicate a possible occurrence of chronic oxidation.

The inhibition significative of CAT activity was another important result in this study (Table 3). A mechanistic explanation for this finding is that the generated oxygen radicals may inhibit thiol groups

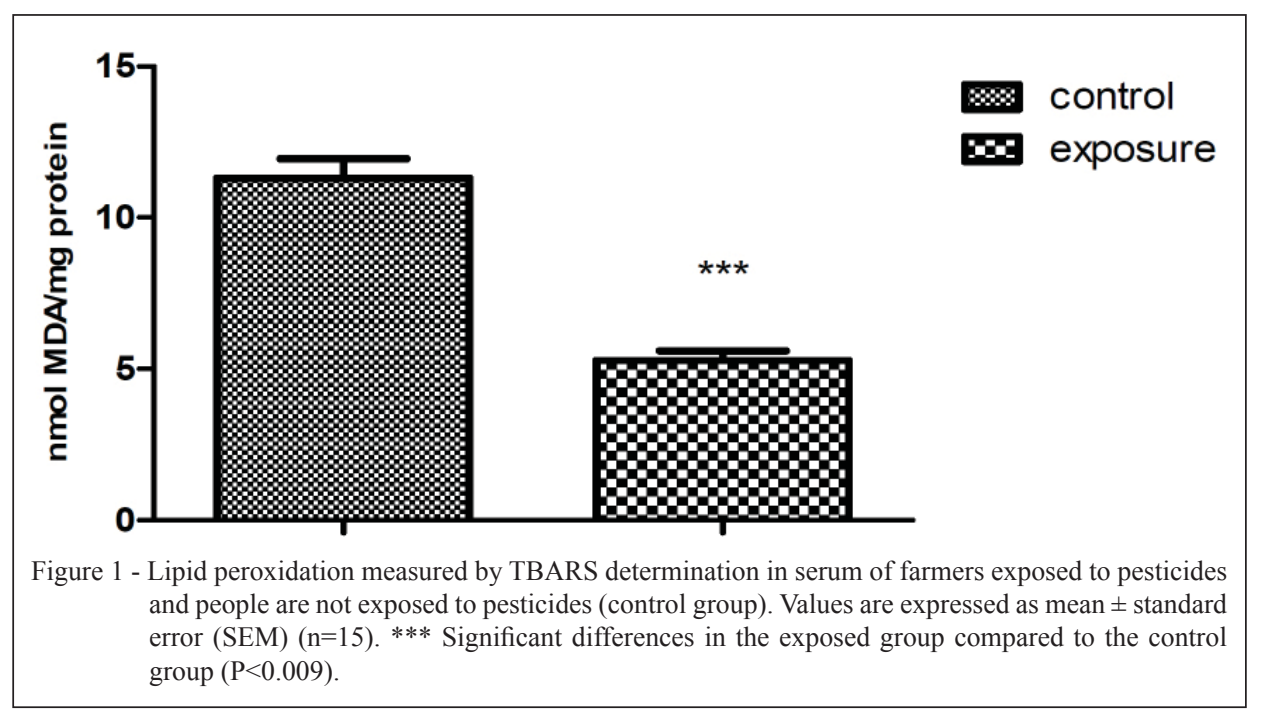

Ciência Rural, v.44, n.7, jul, 2014. 


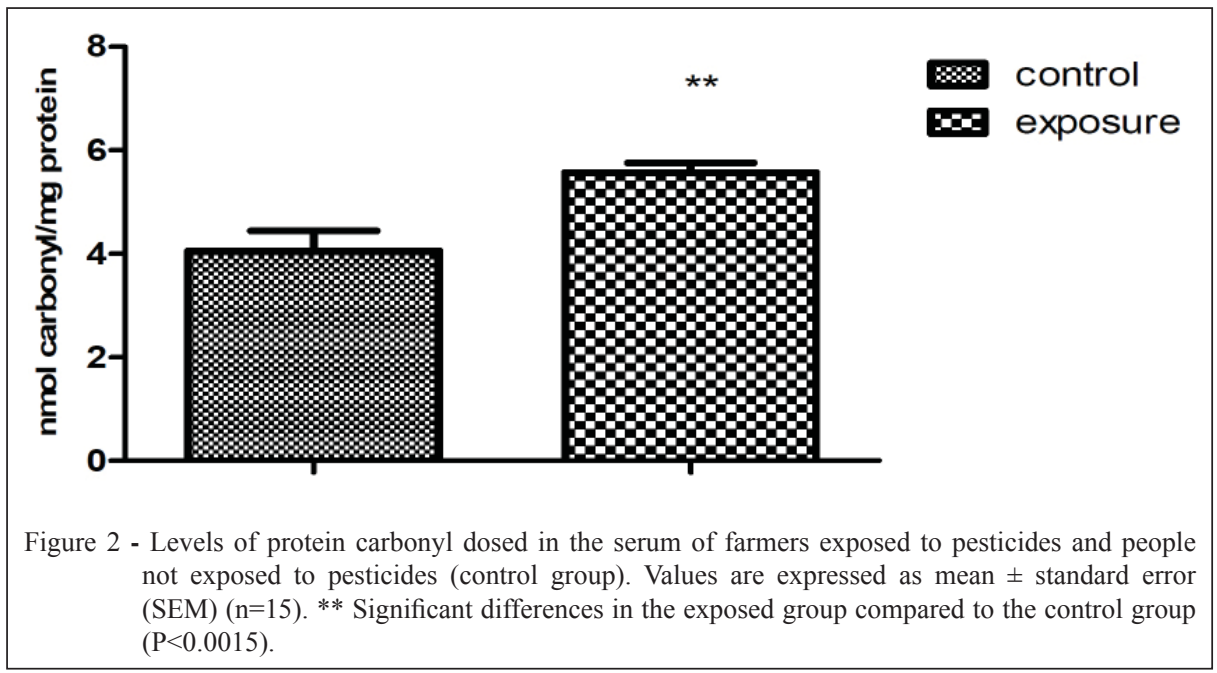

of CAT and thus the resultant excess in hydrogen peroxide may further inhibit SOD, although the precise mechanism involved merits further research (LÓPEZ et al., 2007). The decreased CAT activity found in this study was also demonstrated by SIMONIELLO et al. (2010), who studied the biochemical changes in rural workers exposed to pesticides. This finding is consistent with the lower CAT activity observed in erythrocytes of patients acutely poisoned by dipterex, which is an insecticide (ZHOU et al., 2004). Also, results corroborate SIMONIELLO et al. (2010), who studied the biochemical changes in rural workers exposed to pesticides.

These results show that although still observed an increase in protein carbonyls in these farmers, the endogenous defense is occurring, but not as efficient. However, for clarification further studies are needed to evaluate the possibility of inhibition of the CAT activity and a study of the presence and activity of a large number of endogenous antioxidants in individuals exposed to pesticides, considering that the occurrence of oxidative stress are associated with the onset of pathological processes cardiovascular, neurodegenerative and carcinogenic (BARBOSA et al., 2010).

\section{CONCLUSION}

Analyzing the results, it was concluded that the intense handling pesticides alter the oxidative status of rural workers, inhibits AChE activity and changes, although no diagnostic value, the activity of liver enzymes ALT and AST. Therefore, these results show the importance of greater care in handling these xenobiotics, as well as an increased biological monitoring of these workers exposed to pesticides as a means of prevention.

\section{ETHICS COMITTEE AND BIOSECURITY}

This study was submitted to the research ethics committee of the University of Cruz Alta and was approved under protocol n.0071.0.417.000-11.

\section{ACKNOWLEDGEMENTS}

We would like to thank the University of Cruz Alta (UNICRUZ) for the support, facilities and by research fellowship granted in the Scholarship Program for Scientific Initiation (PIBICUNICRUZ), n. protocol: 026 .

\section{REFERENCES}

AMORIM, L.C.A. Biomarkers for evaluating exposure to chemical agents present in the environment. Rev Bras Epidemiol, v.6, n.2, p.158, 2003.

ANVISA (AGÊNCIA NACIONAL DE VIGILÂNCIA SANITÁRIA). Available from: <http://www.anvisa.gov.br.>. Online. Accessed: Feb. 18, 2013.

ANDRADE J.R. et al. Oxygen free radicals and pulmonary disease. J Bras Pneumol, v.31, n.1, p.60-68, 2005.

ASTIZ, M. et al. Occupational exposure characterization in Professional sprayers: clinical utility of oxidative stress biomarkers. Environ Toxicol Pharmacol, v.32, p.249-258, 2011. Available from: $<$ http://www.ncbi.nlm.nih.gov/pubmed/21843806>. Accessed: Mar. 10, 2013. doi: 10.1016/j.etap.2011.05.010.

BAGIS, S. et al. Free radicals and antioxidants in primary fibromyalgia: an oxidative stress disorder? Rheumatol Int, v.25, n.3, p.188-190, 2005.

BARBOSA K.B.F. et al. Oxidative stress: concept, implications and modulating factors. Rev Nutr, v.2, n.4, p.629-643, 2010. 
BARREIROS, A.L.B.S.; DAVID, J.M. Oxidative stress: relations between the formation of reactive species and the organism's defense. Quím Nova, v.29, p.113-123, 2006. Available from: $<$ http://www.scielo.br/scielo.php?script $=$ sci arttext\&pid $=$ S0100-0422006000100021 $>$. Accessed: Feb. 25, 2013. doi: $10.1590 / \mathrm{S} 0100-40422006000100021$

BRADFORD, M.M.A. A rapid and sensitive method for the quantification of microgram quantities of protein utilizing the principle of protein-dye binding. Anal Biochem, v.72, p.248-254, 1976.

BUEGE, J.A.; AUST, S.D. Microssomal lipid peroxidation. Method Enzymol, v.52, p.302-309, 1978.

BUKOWSKA, B.; HUTNIKA, K. 2, 4-D and MCPA and their derivatives: effect on the activity of membrane erythrocytes acetylcholinesterase (in vitro). Pestic Biochem Physiol, v.85, p.174-180, 2006.

CATTANEO, R. et al. Toxicological responses of Cyprinus carpio exposed to the herbicide penoxsulam in rice field conditions. $\mathbf{J}$ Appl Toxicol, v.31, p.626-632, 2011. Available from: <http:// www.ncbi.nlm.nih.gov/pubmed/21204108>. Accessed: Mar. 10, 2013. doi: 10.1002/jat.1606.

CATANO, H.C. et al. Plasma cholinesterase levels and health symptoms in Peruvian farm workers exposed to organophosphate pesticides. Arch Environ Contam Toxicol, v.55, p.153-159, 2008.

CIMEN, M.Y. Free radical metabolism in human erythrocytes. Clin Chim Acta, v.390, p.1-11, 2008.

DALLE DONNE, I. et al. Protein carbonyl groups as biomarkers of oxidative stress. Clin Chim Acta, v.329, p.2338, 2003. Available from: <http://www.ncbi.nlm.nih.gov/ pubmed/12589963 $>$. Accessed: Feb. 18, 2013. doi: 10.1016/ S0009-8981(03)00003-2.

DERESZ, L.F. et al. Oxidative stress and physical exercise in HIV positive individuals. Rev Bras Med Esp, v.13, p.275-279, 2007.

ELLMAN, G.L. et al. A new and rapid colorimetric determination of acetylcholinesterase activity. Biochem Pharmacol, v.7, p.8895, 1961. Available from: <http://www.sciencedirect.com/science/ article/pii/0006295261901459>. Accessed: Feb. 23, 2013. doi: 10.1016/0006-2952(61)90145-9.

ELY, J.F. et al. Enzymatic changes resulting from skeletal muscle ischemia in rats. Acta Cir Bras, v.15, n.3, 2000. Available from: $\quad<$ http://www.scielo.br/scielo.php?script=sci arttext\&pi $\mathrm{d}=\mathrm{S} 0102-86502000000300002>$. Accessed: Jul. 15, 2012. doi: $10.1590 / \mathrm{S} 0102-86502000000300002$

GAW, A. et al. Clinical Biochemistry. 4.ed. Reprinted. Churchill Livingstone: Elsevier, 2008. 188p.

INSTITUTO BRASILEIRO DE GEOGRAFIA E ESTATÍSTICA (IBGE). Synthesis of Social Indicators: an analysis of the living conditions of the population. Rio de Janeiro, 2010. Available from: $<$ http://www.ibge.gov.br/home/estatistica/populacao/condicaodevida/ indicadoresminimos/sinteseindicsociais2010/SIS 2010.pdf.>. Accessed: Aug. 10, 2012.
JINTANA, S. et al. Cholinesterase activity, pesticide exposure and health impact in a population exposed to organophosphates. Int Arch Occup Environ Health, v.82, p.833-842, 2008. Available from: <http://link.springer.com/article/10.1007/s00420-009-04229\#page-1>. Accessed: Jan. 09, 2013. doi: 10.1007/s00420-0090422-9.

LEITE,I.C.etal. Comparisonofinformationontheprevalence of chronic diseases obtained by the supplement and health PNAD/98 estimated by the study Burden of Disease in Brazil. Sci Health Magazine, v.7, p.733-741, 2002. Available from: <http:/www.scielosp.org/ scielo.php?pid=S1413-81232002000400010\&script=sci_arttext $>$. Accessed: Nov. 07, 2012. doi: 10.1590/S1413-81232002000400010.

LINARES, C.E.B. et al. Baseline levels of acetylcholinesterase and butyrylcholinesterase farmers in the region of Frederico Westhepalen-RS. Health, v. 31, p.47-51, 2005.

LÓPEZ, O. et al. Changes in antioxidant enzymes in humans with long-term exposure to pesticides. Toxicol Letters, v.171, p.146-153, 2007. Available from: <http://www.sciencedirect. com/science/article/pii/S0378427407001439>. Accessed: Jan. 07, 2013. doi: 10.1016/j.toxlet.2007.05.004.

MANSOUR, S.; MOSSA, A. Lipid peroxidation and oxidative stress in rat erythrocytes induced by chlorpyrifos and the protective effect of zinc. Pestic Biochem Physiol, v.97, p.34-39, 2009.

MUNIZ, J.F. et al. Biomarkers of oxidative stress and DNA damage in agricultural workers: A pilot study. Toxicol App Pharmacol, v.227, p.97-107, 2008.

NELSON, D.P.; KIESOV, L.A. Enthalphy of decomposition of hydrogen peroxide by catalase at $25^{\circ} \mathrm{C}$ (with molar extinction coefficients of $\mathrm{H}_{2} \mathrm{O}_{2}$ solution in the UV). Anal Biochem, v.49, p.474-478, 1972.

OGA, S. Fundamentals of toxicology. 2.ed. São Paulo: Atheneu, 2003. 474p.

ROEX, E.W.M. et al. Acetylcholinesterase inhibition and increased food consumption rate in the zebrafish, Danio rerio, after chronic exposure to parathion. Aquat Toxicol, v.64, p.451-460, 2003. Available from: $<$ http://www.sciencedirect.com/science/article/pii/ S0166445X03001000>. Accessed: Dez. 05, 2012. doi: 10.1016/ S0166-445X(03)00100-0.

RUAS, C.B. et al. Oxidative stress biomarkers of exposure in the blood of cichlid species from a metal-contaminated river. Ecotoxicol Environ Saf, v.71, p.86-93, 2008.

SIMONIELLO, M.F. et al. Biochemical evaluation of rural workers exposed to pesticides. Medicine, v.70, p.489-498, 2010.

SANTI, A. et al. Oxidative stress biomarkers and acetylcholinesterase activity in human erythrocytes exposed to clomazone (in vitro). Interdiscip Toxicol, v.4, n.3, p.149153, 2011. Available from: <http://www.ncbi.nlm.nih.gov/ pubmed/22058656>. Accessed: Jan. 10, 2013. doi: 10.2478/ v10102-011-0023-9.

SLEDZINSKI, T. et al. Decrease in serum protein carbonyl groups concentration and maintained hyperhomocysteinemia in patients Undergoing Bariatric Surgery. Obes Surg, v.19, n.3, p.321-326, 2008 . 
TROUDI, A. et al. Oxidative damage in bone and erythrocytes of suckling rats exposed to 2,4-dichlorophenoxyacetic acid. Pest Biochem Physiol, v.104, p.19-27, 2012. Available from: <http:// www.sciencedirect.com/science/article/pii/S0048357512000922>. Accessed: Mar. 20, 2013. doi: 10.1016/j.pestbp.2012.06.005.

VASCONCELOS, S.M.L. et al. Reactive oxygen and nitrogen species, antioxidants and markers of oxidative damage in human blood: main analytical methods for their determination. Quím Nova, v.30, p.1323-1338, 2007.
VEIGA, M.M. et al. The contamination by pesticides and Personal Protective Equipment (PPE). J Occup Health, v.32, p.57-68, 2007

YAN, L.J. et al. Spectrophotometric method for determination of carbonyls in oxidatively modified apolipoprotein B of human lowdensity lipoproteins. Anal Biochem, v.228, p.349-351, 1995.

ZHOU, J.F. et al. Oxidative stress and free radical damage in patients with acute dipterex poisoning. Biomed Environ Sci, v.17, p.223-233, 2004. 